\title{
INTEGRACJA RACHUNKU KOSZTÓW KLIENTA Z WYBRANYMI METODAMI RACHUNKOWOŚCI ZARZĄDCZEJ
}

\begin{abstract}
Globalizacja wpływa na wiele aspektów funkcjonowania przedsiębiorstw. Z jednej strony powoduje znaczący wzrost konkurencyjności rynków i możliwości prowadzenia działalności gospodarczej, a z drugiej strony ułatwia przepływ kapitału intelektualnego, technologii oraz zasad i metod prowadzenia tej działalności. Przedsiębiorstwa budują swoją przewagę konkurencyjną na różne sposoby. Jednym z elementów efektywnego zarządzania przedsiębiorstwami jest umiejętne wdrożenie i prowadzenie rachunku kosztów dostosowanego do potrzeb danego przedsiębiorstwa. Dla każdego przedsiębiorstwa najważniejszym źródłem przychodów są klienci. $Z$ tego powodu utrzymywanie rentownych relacji z klientami jest kluczowe dla możliwości prowadzenia i rozwijania się tych przedsiębiorstw. Skutecznym narzędziem w optymalizacji rentowności tych relacji jest rachunek kosztów klienta. Dla przedsiębiorstw prowadzących swoją działalność w większym rozmiarze, które stosują $w$ swoich systemach zarzadzania różne metody rachunkowości zarządczej najlepszym rozwiązaniem będzie odpowiednia integracja tych metod $\mathrm{z}$ rachunkiem kosztów klienta. Integracja ma na celu zapewnić wzmocnienie pozytywnych walorów decyzyjnych łączonych systemów. Rachunek kosztów klienta można $\mathrm{z}$ powodzeniem dostosować nie tylko do rozmiarów prowadzonej działalności, ale także zintegrować go $\mathrm{z}$ wykorzystywanymi $\mathrm{w}$ danym przedsiębiorstwie metodami rachunkowości zarządczej. Wśród najchętniej wykorzystywanych metod rachunkowości zarządczej w przedsiębiorstwach można wyróżnić: zarządzanie działaniami, budżetowanie, rachunek kosztów docelowych, rachunek kosztów ciągłego doskonalenia, zrównoważoną kartę wyników. Celem artykułu jest analiza podstawowych zasad integracji rachunku kosztów klienta $\mathrm{z}$ wymienionymi metodami rachunkowości zarządczej. Artykuł ten może być istotnym przyczynkiem do podjęcia szerszych badań, których celem jest poddanie bardziej szczegółowej analizie zasad takiej integracji.
\end{abstract}

Słowa kluczowe: rachunek kosztów, klient, integracja.

\section{WPROWADZENIE}

Przedsiębiorstwa działają pod presją coraz bardziej konkurencyjnego rynku oraz rosnących wymagań klientów, którzy także coraz częściej stosują różne narzędzia optymalizacji swoich relacji z klientami np. grupy zakupowe ${ }^{2}$.Konsekwencją działania na globalizujących się rynkach jest $\mathrm{z}$ jednej strony proces zwiększania się stopnia trudności zarządzania takimi przedsiębiorstwami, a z drugiej strony możliwy jest łatwiejszy dostęp

\footnotetext{
1 Dr Grzegorz Lew, Zakład Finansów, Bankowości i Rachunkowości, Wydział Zarządzania, Politechnika Rzeszowska, email: lewgrzes@ prz.edu.pl

${ }^{2} \mathrm{G}$. Zimon, Zarzadzanie kosztami w jednostkach tworzacych branżowe grupy zakupowe, w: Finanse, Rynki Finansowe, Ubezpieczenia, z.757/58, Wydawnictwo Naukowe Uniwersytetu Szczecińskiego, Szczecin 2013, s.293-299, H. Chłodnicka, G. Zimon, Analiza kosztów w przedsiębiorstwach tworzacych grupy zakupowe, Finanse, Rynki Finansowe, Ubezpieczenia, z.765/61, Wydawnictwo Naukowe Uniwersytetu Szczecińskiego, Szczecin 2013, s.293-303.
} 
do wiedzy i doświadczeń przedsiębiorstw z różnych regionów świata, w kwestii rozwiązywania coraz bardziej złożonych problemów decyzyjnych. Globalizacja wpływa również na przepływ kapitału intelektualnego pomiędzy rozwiniętymi a rozwijającymi się krajami, regionami czy przedsiębiorstwami. Zjawiska te implikują wzrost stopnia zaawansowania systemów pozwalających na efektywne wspomaganie decyzji podejmowanych przez zarządzających. Jedną z możliwości zwiększenia efektywności metod stosowanych $\mathrm{w}$ rachunkowości zarządczej jest ich integracja. Integracja, inaczej scalanie jest procesem tworzenia całości z części, włączeniem jakiegoś elementu w całość, zharmonizowaniem składników zbiorowości ${ }^{3}$.

Biorąc pod uwagę wzrost istotności oraz jakości uzyskiwanych informacji o kosztach klientów należy wymienić następujące powody integracji różnych metod rachunkowości zarządczej z rachunkiem kosztów klienta:

- integracja różnych metod rachunkowości zarządczej może wywołać efekt synergii,

- możliwość wzmocnienia najskuteczniejszych w działaniu elementów integrowanych metod,

- marginalizacja negatywnych skutków wdrożenia i prowadzenia podlegających integracji metod,

- możliwość optymalizacji metod, podczas ich integracji, pod względem indywidualnych potrzeb konkretnego przedsiębiorstwa.

Celem efektu synergii integracji metod rachunkowości zarządczej w rachunku kosztów klienta przedsiębiorstw jest uzyskanie znaczenie większych korzyści niż przy oddzielnym stosowaniu jednej z metod. Przykładowo, rachunek kosztów klienta może być prowadzony $\mathrm{w}$ trybie ex post i ex ante. Takie podejście do rachunku kosztów klienta umożliwia integracja tego rachunku z systemem budżetowania kosztów klienta. Z kolei podejście eksponujące działania zwiększające wartość dla klienta jest możliwe przy integracji rachunku kosztów klienta z rachunkiem kosztów działań.

Kolejnym powodem integracji rachunku kosztów klienta $\mathrm{z}$ różnymi metodami rachunkowości zarządczej jest możliwość poddania integracji najbardziej efektywnych elementów składających się na poszczególne metody rachunkowości zarządczej. Działania takie mogą spowodować powstanie nowej jakości w dedykowanych metodach rachunkowości zarządczej stosowanej w konkretnych przedsiębiorstwach handlowych.

Powodem powiązanym z poprzednim jest możliwość uniknięcia, dzięki integracji, niektórych niekorzystnych rozwiązań związanych $\mathrm{z}$ poszczególnymi metodami rachunkowości zarządczej. Przykładowo w literaturze spotkać można liczne przykłady krytykowania budżetowania ${ }^{4}$, jednak metoda ta jest powszechnie stosowana, z powodu swojej prostoty i elastyczności. Chociaż mimo tego trudno jest uniknąć zarzutu zbyt dużego zbiurokratyzowania tej metody.

\footnotetext{
${ }^{3}$ W. Kopaliński, Podręczny słownik wyrazów obcych, Oficyna Wydawnicza Rytm, Warszawa 1999, s. 340.

${ }^{4}$ J. Hope oraz R. Fraser wyrażają opinię, że budżetowanie jest metodą ograniczającą możliwości efektywnego funkcjonowania przedsiębiorstw. W wielupublikacjachpropagowaliswojąkoncepcję „,bezbudżetowania” np.: J. Hope, R. Fraser, Beyond Budgeting: How Managers Can Break Free from the Annual Performance Trap, Harvard Business School, Boston 2003. Krytykę tradycyjnego budżetowania znaleźć można również w raporcie CIMA: Beyond Budgeting, CIMA, Topic Gateway Series No. 35, London 2007.
} 
Argumentem niewątpliwie istotnym, motywującym do integracji rachunku kosztów klienta $\mathrm{z}$ różnymi metodami rachunkowości, jest możliwość dostosowania tych metod rachunkowości zarządczej do specyficznych potrzeb konkretnego przedsiębiorstwa handlowego. Obecnie coraz rzadziej mówi się o rozwiązaniach uniwersalnych. Każde przedsiębiorstwo handlowe jest inne, funkcjonuje w innym otoczeniu, w innym rozmiarze i musi rozwiązywać swoje problemy. W związku z tym istnieje potrzeba łączenia różnych metod rachunkowości zarządczej, które w najlepszym stopniu odpowiadają indywidualnym potrzebom poszczególnych przedsiębiorstw handlowych.

Celem artykułu jest analiza podstawowych zasad integracji rachunku kosztów klienta z wybranymi metodami rachunkowości zarządczej.

\section{RACHUNEK KOSZTÓW KLIENTA}

W literaturze spotyka się różne definicje rachunku kosztów. E. Nowak ${ }^{5}$ definiuje go jako proces „ustalania kosztów działalności gospodarczej polegającej na wytwarzaniu i sprzedaży wyrobów lub świadczeniu usług czy też obrotu towarami”. Rachunek kosztów to także „ogół czynności zmierzających do ustalenia wysokości nakładów pracy żywej i uprzedmiotowionej, poniesionych $\mathrm{w}$ przedsiębiorstwie $\mathrm{W}$ określonym czasie i z określonym przeznaczeniem"6 lub badanie i przetwarzanie, według przyjętego modelu, informacji o kosztach działalności podmiotu, służące użytkownikom do oceny sytuacji finansowej, podejmowania decyzji gospodarczych i kontroli ich realizacji ${ }^{7}$.

Z tych definicji wynika, iż model rachunku kosztów określa cel, przedmiot i podmiot tego rachunku. W rachunku kosztów klienta można uznać, że:

- celem jego prowadzenia jest dostarczenie zarządzającym użytecznych decyzyjnie informacji na temat kosztów związanych z relacjami z klientami oraz w efekcie umożliwienie ustalenia rentowności tych relacji,

- przedmiotem pomiaru są koszty klienta lub segmentu klientów,

- podmiotem, w którym ten pomiar jest dokonywany jest przedsiębiorstwo handlowe prowadzace ten rachunek kosztów.

A zatem rachunek kosztów klienta należy definiować jako proces identyfikacji, klasyfikacji, pomiaru, wyceny, gromadzenia, rozliczania (kalkulowania), analizowania oraz prezentacji kosztów wynikających z nawiązywania, utrzymywania i prowadzenia relacji z klientami oraz wykorzystania zasobów na potrzeby obsługi tych relacji w sposób umożliwiający ustalenie skumulowanych kosztów klienta lub segmentu klientów ${ }^{8}$.

Rachunek kosztów klienta jest bazą ustalenia rentowności klientów lub ich segmentów. Aby możliwe było ustalenie rentowności klientów, identyfikację i analizę przychodów osiąganych dzięki tym klientom należy prowadzić $\mathrm{z}$ taką samą szczegółowością dotyczącą klientów lub ich segmentów jak jest stosowana do identyfikacji kosztów. Pozwoli to na ustalenie wyniku finansowego w przekroju klientów, a odpowiednia konstrukcja rachunku wyników umożliwi prześledzenie wpływu danych obiektów kosztowych na ogólną rentowność poszczególnych klientów.

E. Nowak, Rachunek kosztów w jednostkach gospodarczych. Podejście sprawozdawcze $i$ zarządcze, Ekspert, Wrocław 2011, s. 13.

${ }^{6}$ J. Matuszewicz, Rachunek kosztów, Finans - Servis, Warszawa 1994, s. 4.

${ }^{7}$ A. Jarugowa, W. Malc, K. Sawicki, Rachunek kosztów, PWE, Warszawa 1990, s. 54.

8 G. Lew, Rachunek kosztów klienta $w$ zarządzaniu przedsiębiorstwem handlowym, Oficyna Wydawnicza Politechniki Rzeszowskiej, Rzeszów 2015. 
Rachunek kosztów klienta powinien zatem obejmować swoim zakresem całość działań przedsiębiorstwa, tak aby $\mathrm{w}$ kompleksowy sposób wspierać zarządzających w podejmowaniu przez nich decyzji. Rachunek kosztów jest wyodrębnionym przedmiotowo oraz proceduralnie systemem informacyjnym przedsiębiorstwa.

Rachunek kosztów klienta jest jednolitym zbiorem informacji o kosztach klienta opracowanych według określonego modelu dostosowanego do potrzeb konkretnych użytkowników w danym przedsiębiorstwie handlowym.

\section{INTEGRACJA $Z$ WYBRANYMI METODAMI RACHUNKOWOŚCI \\ ZARZĄDCZEJ}

Można stwierdzić, ze przedstawienie wszystkich sposobów integracji różnych metod rachunkowości zarządczej z rachunkiem kosztów klienta nie jest możliwe. Zapewne jest ich tyle ile przedsiębiorstw i osób mających pomysł na wdrożenie takiej koncepcji. Z tego powodu, analizie możliwości integracji z rachunkiem kosztów klienta zostanie poddanych kilka, najbardziej rozpoznawalnych metod rachunkowości zarządczej. Zaliczyć do nich należy integrację rachunku kosztów klienta $\mathrm{z}$ :

- systemem zarządzania działaniami (ABM-activity-based management),

- systemem budżetowania,

- rachunkiem kosztów docelowych funkcjonującym wraz z koncepcją ciągłego doskonalenia kaizen,

- zrównoważoną kartą wyników.

Koncepcja integracji rachunku kosztów klienta z metodą zarządzania działaniami opiera się na założeniu, że wszelkie działania podejmowane przez przedsiębiorstwa handlowe mają za zadanie tworzyć wartość dla klientów. Według słownika CAM-I, $A B M$ to metoda skoncentrowana na zarządzaniu procesami i działaniami jako metodzie podnoszenia wartości dla klientów oraz zwiększania zysków powstających dzięki tworzeniu tej wartości ${ }^{9}$. Obejmuje analizę czynników kosztotwórczych, analizę działań, jak również pomiar efektów tych działań. Koncepcja $A B M$ wykorzystuje jako źródło informacji rachunek kosztów działań ( $A B C$ - Activity basedcosting). Ewolucję koncepcji związanych z działaniami przedstawia rys. 1 .

\begin{tabular}{|c|c|c|}
\hline $\begin{array}{c}\text { ABC } \\
\text { Activivty-based costing }\end{array}$ & $\begin{array}{c}\text { ABCM } \\
\text { Activity-based cost management }\end{array}$ & $\begin{array}{c}\text { ABM } \\
\text { Identyfikacja działań, } \\
\text { ich wycena } \\
\text { i kalkulacja kosztów }\end{array}$ \\
$\begin{array}{c}\text { Rozpoznanie struktury kosztów, } \\
\text { ich zachowania, } \\
\text { zarządzanie kosztami }\end{array}$ & $\begin{array}{c}\text { Podejmowanie decyzji } \\
\text { mających za celu zwiększanie } \\
\text { wartości przedsiębiorstwa } \\
\text { i wartości dla klienta }\end{array}$ \\
\hline
\end{tabular}

Rysunek 1. Ewolucja koncepcji zarządzania kosztami oparta na działaniach

Źródło: Opracowanie własne na podstawie: Nita B., Rachunkowość w zarządzaniu strategicznym przedsiębiorstwem, WoltersKluwer business, Kraków 2008, s. 197.

Jeżeli przedsiębiorstwo identyfikuje działania przynoszące wartość dla klienta oraz nie przynoszące wartości dla klienta integracja rachunku kosztów klienta z activity-based

\footnotetext{
9 J.A. Miller, współpraca K. Pniewski, M. Polakowski, Zarządzanie kosztami działań, WIG-Press, Warszawa 2000, s 210.
} 
management jest rozwiązaniem, które w sposób kompleksowy jest w stanie wspierać decyzje zarządzających w zakresie optymalizacji relacji z klientami.

Drugą koncepcją integracji rachunku kosztów klienta jest możliwość integracji tego rachunku z systemem budżetowania. Mimo krytyki tego systemu przez niektórych autorów, należy uznać, że jest to koncepcja, która dzięki prostym zasadom funkcjonowania ma realne możliwości stosowania w przedsiębiorstwach. Instytut CIMA w swoim raporcie ${ }^{10}$ przedstawia za J. Hopem i R. Fraserem sześć wspólnych zasad używanych przez przedsiębiorstwa, które wybrały koncepcję „bez budżetowania” jako alternatywę dla tradycyjnego budżetowania:

1. Dla wszystkich szczebli zarządzania przyjmuje się jasne zasady, wartości i granice. Promuje się współdziałanie i optymalną obsługę klientów.

2. Kluczowe znaczenie mają właściwe działania poparte widocznymi i realnymi dokonaniami (a nie realizacją założeń budżetowych) na wszystkich szczeblach zarządzania, co ma sprzyjać wspieraniu wzajemnej poprawy efektywności działania z wykorzystaniem wewnętrznej konkurencji i satysfakcji klientów.

3. Pracownicy „,z pierwszej linii frontu” mają swobodę podejmowania decyzji (nie są ograniczeni budżetami) zgodnie $\mathrm{z}$ zasadami ładu korporacyjnego oraz strategicznych celami przedsiębiorstwa. Ma to decydujące znaczenie dla poczucia bezpieczeństwa pracowników i realizacji strategii przez nich wszystkich. Promowane są wysokie standardy działania, oraz stosowanie optymalnych wzorców (właściwych benchmarków).

4. Pracownicy biorą odpowiedzialność za tworzenie swoich systemów działania i wartości. Zasada ta dotyczy również jednostek wewnętrznych, które mają swobodę zarządzania własnymi zasobami, ale jednocześnie są za nie odpowiedzialne.

5. Wszystkie jednostki wewnętrzne koncentrują się na klientach, co ma prowadzić do większej efektywności ich obsługi oraz zwiększenia ilości klientów zadowolonych i rentownych.

6. Systemy informacyjne w przedsiębiorstwach mają być otwarte i przejrzyste w celu generowania bardziej wiarygodnych informacji zgodnych z zasadami etycznymi.

Jednak integracja budżetowania z rachunkiem kosztów klienta może pozwolić uniknąć wielu niekorzystnych zjawisk towarzyszących budżetowaniu. Sami krytycy ${ }^{11}$, wśród metod rachunkowości zarządczej mających pozytywny wpływ na niwelację niekorzystnych skutków budżetowania wymieniają zarządzanie relacjami z klientami czy prognozowanie (budżetowanie) kroczące.

Rachunek kosztów docelowych przystosowany do specyfiki przedsiębiorstw jest potencjalną metodą, którą można wykorzystać do optymalizacji kosztów relacji z klientami. Potencjał tej formy integracji w istotny sposób zwiększyć może wykorzystanie przy jej stosowaniu filozofii kaizen, która zakłada ciągłe doskonalenie działan, co w kontekście optymalizacji relacji z klientami nabiera szczególnego znaczenia.

Koncepcję kaizen przedsiębiorstwa mogą wykorzystać przy poszukiwaniu odpowiedzi na pytanie: Dlaczego obecni klienci dokonują zakupów w naszym przedsiębiorstwie? Umiejętność zidentyfikowania czynników mających wpływ na decyzje klientów ma

\footnotetext{
${ }^{10}$ Beyond Budgeting, CIMA, Topic Gateway Series no. 35, London 2007, s. 6.

11 J. Hope, R. Fraser, Beyond Budgeting: How Managers Can Break Free from the Annual Performance Trap, Harvard Business School, Boston 2003, s. 179.
} 
kluczowe znaczenie dla ich utrzymania oraz daje możliwość wykorzystania tych informacji do optymalizacji kosztów pozyskiwania nowych klientów.

Integracja rachunku kosztów klienta $\mathrm{z}$ zrównoważoną kartą wyników nastąpić może niejako w sposób naturalny. Dzieje się tak ponieważ R.S. Kaplan i D.P. Norton ${ }^{12}$ przedstawiają kartę jako narzędzie, które umożliwia przełożenie wizji i strategii przedsiębiorstwa na zestaw powiązanych ze sobą mierników efektywności działania przedsiębiorstwa. Cele przedsiębiorstwa powinny określać jego kierunek rozwoju w perspektywie co najmniej kilku lat ${ }^{13}$. Kaplan i Norton cele oraz mierniki zgrupowali w czterech perspektywach:

- finansowej,

- klienta,

- procesów wewnętrznych,

- rozwoju przedsiębiorstwa.

Wyróżnione perspektywy umożliwiają według autorów zachowanie równowagi między celami krótko- i długoterminowymi oraz między oczekiwanymi wynikami a czynnikami warunkującymi ich realizację. Proponowane przez nich mierniki osiągania celów w perspektywie klienta doskonale wpisują się w podstawowe założenia rachunku kosztów klienta, w szerokim rozumieniu znaczenia tego pojęcia. Dzięki integracji rachunku kosztów klienta z zrównoważoną kartą wyników możliwe jest odpowiednie ustalenie rentowności relacji z klientami przy zachowaniu innych mierników tych relacji na właściwym poziomie.

Reasumując rachunek kosztów klienta dzięki możliwości integracji z różnymi narzędziami rachunkowości zarządczej może bardziej twórczo wykorzystywać ich walory zarządcze i w efektywniejszy - z ekonomicznego punktu widzenia - sposób wskazywać alokację zasobów w celu osiągnięcia zysku finansowego ${ }^{14}$ przez przedsiębiorstwa.

\section{PODSUMOWANIE}

Głównym powodem podjęcia badań związanych z integracją $\mathrm{w}$ ramach rachunkowości zarządczej lub rachunku kosztów jest stwierdzenie, że projektowanie nowych zintegrowanych rachunków kosztów, w tym także rachunku kosztów klienta, jest zapewne kierunkiem rozwoju rachunkowości zarządczej, w którym będzie się ona rozwijać we współczesnej nauce i praktyce.

W ramach dociekań naukowych nie jest możliwe wyczerpanie wszelkich możliwych sposobów integracji rachunku kosztów klienta $\mathrm{z}$ różnymi metodami rachunkowości zarządczej. Z tego powodu w artykule ograniczono się do przedstawienia kilku najbardziej, w ocenie autora, perspektywicznych kierunków integracji, które mają największe szanse na uznanie w praktyce gospodarczej po uprzednim zweryfikowaniu zasadności wdrożenia i uszczegółowieniu modelu naukowego pod względem specyfiki konkretnego przedsiębiorstwa.

\footnotetext{
${ }^{12}$ R.S. Kaplan, D.P. Norton, Strategiczna karta wyników. Jak przelożyć strategię na działanie, Wydawnictwo Naukowe PWN, Warszawa 2006.

${ }^{13}$ Strategia. Opracuj $i$ zastosuj najlepsza strategię dla swojej firmy, przełożył: M. Kowalczyk, Harvard Business Essentials, MT Biznes, Warszawa 2011, s. 125.

${ }^{14}$ M. Sierpińska, B. Niedbała, Controlling operacyjny w przedsiębiorstwie, Wydawnictwo Naukowe PWN, Warszawa 2003, s. 386.
} 
Wskazane w artykule kierunki integracjina podstawie doświadczeń autora pozwalają sformułować zasadniczy wniosek, że podstawowe założenia poszczególnych metod rachunkowości zarządczej, które stanowią fundamenty ich funkcjonowania nie są konkurencyjne wobec siebie, tylko mogą być traktowane jako komplementarne. Takie stwierdzenie leży u podstaw zasadności integracji rachunku kosztów klienta z metodami rachunkowości zarządczej, ponieważ integracja ta może przyczynić się do zwiększenia zakresu i wiarygodności informacji potrzebnych do optymalizacji relacji z klientami.

\section{LITERATURA}

[1] Beyond Budgeting, CIMA, Topic Gateway Series No. 35, London 2007.

[2] Chłodnicka H., ZimonG., Analiza kosztów w przedsiębiorstwach tworzacych grupy zakupowe, Finanse, Rynki Finansowe, Ubezpieczenia, z.765/61, Wydawnictwo Naukowe Uniwersytetu Szczecińskiego, Szczecin 2013.

[3] HopeJ., FraserR., Beyond Budgeting: How Managers Can Break Free from the Annual Performance Trap, Harvard Business School, Boston 2003.

[4] JarugowaA., MalcW., SawickiK., Rachunek kosztów, PWE, Warszawa 1990.

[5] KaplanR.S., NortonD.P., Strategiczna karta wyników. Jak przełożyć strategię na działanie, Wydawnictwo Naukowe PWN, Warszawa 2006.

[6] KopalińskiW., Podręczny słownik wyrazów obcych, Oficyna Wydawnicza Rytm, Warszawa 1999.

[7] Lew G., Rachunek kosztów klienta $w$ zarządzaniu przedsiębiorstwem handlowym, Oficyna Wydawnicza Politechniki Rzeszowskiej, Rzeszów 2015.

[8] MatuszewiczJ., Rachunek kosztów, Finans - Servis, Warszawa 1994.

[9] MillerJ.A., współpraca K. Pniewski, M. Polakowski, Zarządzanie kosztami działań, WIG-Press, Warszawa 2000.

[10]Nita B., Rachunkowość w zarządzaniu strategicznym przedsiębiorstwem, WoltersKluwer business, Kraków 2008.

[11]NowakE., Rachunek kosztów w jednostkach gospodarczych. Podejście sprawozdawcze i zarzadcze, Ekspert, Wrocław 2011.

[12] SierpińskaM., NiedbałaB., Controlling operacyjny $w$ przedsiębiorstwie, Wydawnictwo Naukowe PWN, Warszawa 2003.

[13] Strategia. Opracuj i zastosuj najlepsza strategię dla swojej firmy, przełożył: M. Kowalczyk, Harvard Business Essentials, MT Biznes, Warszawa 2011.

[14]ZimonG., Zarzadzanie kosztami w jednostkach tworzacych branżowe grupy zakupowe, w: Finanse, Rynki Finansowe, Ubezpieczenia, z.757/58, Wydawnictwo Naukowe Uniwersytetu Szczecińskiego, Szczecin 2013.

\section{INTEGRATION OF CUSTOMER COST ACCOUNTING WITH SELECTED} MANAGEMENT ACCOUNTING METHODS

Globalization affects many aspects of the operation of companies. On the one hand, it causes a significant increase in the competitiveness of markets and business opportunities, and on the other hand, facilitates the flow of intellectual capital, technology and the principles and methods of conducting this activity. Companies build their competitive advantage in various ways. One of the elements of effective business management is skilful implementation and running of costs accounting tailored to the needs of a given company. For each company, the most important source of income are the customers. For this reason, 
maintaining profitable relationships with customers is crucial for opportunities of running and development of these companies. Effective tool in optimizing the profitability of those relationships is customer cost accounting. For companies conducting their business in a larger size, which use in their management systems different methods of management accounting the best solution would be a proper integration of these methods with customer cost accounting. The integration aims to ensure the strengthening of the positive decisionmaking values of connected systems. Customer cost accounting can successfully be adapted not only to the size of the business, but also it can be integrated with management accounting methods used in a given company. Among the most frequently used methods of management accounting in companies can be distinguished: operations management, budgeting, target costing, continuous improvement costing, balanced scorecard. The aim of the article is to analyse the basic principles of integration of customer cost accounting with these methods of management accounting. This article may be an important reason to undertake a broader study whose purpose is to undergo a more detailed analysis of the principles of such integration.

Keywords: cost accounting, customer, integration.

DOI:10.7862/rz.2016.hss.44

Przesłano do redakcji: czerwiec 2016

Przyjęto do druku: wrzesień 2016 